\title{
WHITMAN AT PFAFF'S: COMMERCIAL CULTURE, LITERARY LIFE AND NEW YORK BOHEMIA AT MID-CENTURY
}

\author{
Christine Stansell
}

IN 1859, AFTER LOSING HIS JOB at the Brooklyn Daily Times, Walt Whitman began to spend time at Pfaff's restaurant, a basement saloon in what was then central Manhattan on Broadway near Bleecker. Pfaff's, a meeting place for journalists, critics, writers and artists, had already garnered a reputation as New York's first and only "bohemian" night spot. Whitman would spend the next three years at Pfaff's, sitting out the long period of critical silence that followed the second edition of Leaves of Grass. He was only barely and intermittently employed and living at home in Brooklyn, so Pfaff's became, in these years, his chief source of social intercourse. He sat off to the side-at least he remembered it that way years later-and quietly absorbed the high bonhomie and bright conversation that were the staples of bohemian conviviality. "My own "greatest pleasure at Pfaff's," he told Horace Traubel, "was to look on-to see, talk little, absorb." This is what he saw, as he jotted it down in a poem in his notebook in mid-winter 1861:

The vault at Pfaffs where the drinkers and laughers meet to eat and drink and carouse, While on the walk immediately overhead, pass the myriad feet of Broadway

As the dead in their graves, are underfoot hidden

And the living pass over them, recking not of them,

Laugh on laughters [sic]! Drink on drinkers!

Bandy the jests! Toss the theme from one to another!

Beam up-brighten up bright eyes of beautiful young men!

Eat what you, haveing ordered, are pleased to see placed before you-after the work of the day, now with appetite, eat,

Drink wine-drink beer-raise your voice. ${ }^{2}$

Those who sought Whitman around 1860 usually found him at Pfaff's. In addition to consorting with literary acquaintances-New York writers now entirely forgotten - he brought young doctor friends whom he had met while visiting the sick at the New York Hospital and regularly socialized with a group of young male friends - the "beautiful young men"? - dubbed the "Fred Gray Association" after one of their principals. These bohemian days came to a close in 1862, when Whitman received the news his brother was wounded and departed abruptly for Washington. 
What was Whitman doing at Pfaff's? There are several biographical puzzles. He had long been a man about town, a self-styled plebeian flâneur, but this was the first and only time he habituated a saloon. For most of his adult life Whitman had been committedly abstemious, drawn to health reform and temperance, so the late night carousing and tipsy badinage of the bohemian years seem out of character. Older biographers attributed Whitman's bohemianism to some temporary failure of moral will. Frederick Schyberg, writing in the 1930s, hinted darkly at some deep character flaw activated by a "disturbed and unhappy private life" which led Whitman to "defeat and ruin," running wild with a crowd of "highly disreputable characters." Henry Binns, mulling over a photograph of Whitman from the Pfaff's years, complained that "one cannot help feeling that the man ought to loaf a little less. The head is magnificent but the knees are a little too loose." 3 Then there are questions about literary influence. What role, if any, did such a decidedly minor group of writers play in the development of the great poet? All the Pfaffian writers except Whitman have fallen into obscurity: N. G. Shepherd, Ada Clare, Henry Clapp, Fitz-James O'Brien, George Arnold, Frank Wood, Charles Dawson Shanley.

Paul Zweig, considering this issue, has suggested that at this point in his career Whitman required a "small stage" on which he could play out a developing role of grandiloquence to a "ragtag crowd" of secondraters: "the slightly shady 'actresses,' the acidly witty journalists and down-at-the-heels drinkers." Given the image of the grave which begins Whitman's poem about Pfaff's, Zweig argues, there was a morbid cast to Whitman's socializing, a sense of buried hopes, of invisibility to "the living." "This marginal bohemia was not what he had in mind when he had launched his 'Voice' to the working men and women of America only a few years before." 4 Yet there are also suggestions that bohemia was the setting for more fruitful encounters which helped the poet gather his powers and emotional resources for the third edition of Leaves of Grass and a successful entry into the national literary scene. Justin Kaplan maintains that although the bohemian life "was not naturally Whitman's," he still found the gloomy saloon "a more gemütlich and inspiriting social base than Abby Price's Brooklyn parlor." And while Whitman himself later disparaged the years before he left for Washington as his "New York stagnation" of "horrible sloughs," Zweig notes that the accumulation of his work by 1862 runs against the grain of this judgment: "the 'slough' had been accompanied by a remarkable new surge of poetry; and it had contributed in its way to Whitman's new voice. A book, perhaps his finest single volume, had been published by a legitimate Boston publisher. He had become a public figure, albeit in a small way." The obscure Brooklynite was on his way to becoming a national sage. 
So bohemia may have been germane to the unfolding of Whitman's gifts - but what was bohemia? Literary critics have accepted at face value a cultural category that, on closer historical examination, becomes much more problematic, complicated and interesting. In this essay I want to elaborate on Kaplan's and Zweig's more positive readings of Whitman's bohemianism by examining both Whitman's own history in the late 1850s and that of the Pfaff's crowd, especially its reigning personage Henry Clapp. What was "bohemian" literary life as opposed to other kinds of literary sociability? Who were the self-styled bohemians who became Whitman's companions? What significance does the circle's history hold for a broader understanding of northeastern literary culture at mid-century?

The ascription of "bohemia" involved, in the mid-nineteenth century, a new understanding of the relationship of social class to artistic respectability and of both to metropolitan life. Bohemia both incorporated certain kinds of cultural outsiders and dissenters and made them and their work visible and commercially appealing to urban audiences. Bohemia was one spectacle of a city life that was increasingly seen as replete with curiosities and exotica; as such it could have emerged only in New York, never in smaller and duller Boston or Philadelphia. Bohemia grew out of the democratization of literary life and the increased pace of commercialization in American publishing. If Pfaff's was only a transitory phenomenon and a pale imitation of its Parisian progenitor, if its dramas of artistic identity were overblown, it nonetheless accentuated and furthered a new relationship between artists, New York commerce and literary celebrity - a relationship from which Whitman, the first and quintessential New York poet, would benefit enormously.

\section{The Ambiguities of Bohemia}

The idea of "bohemia" as an urban enclave of cultural outsiders and starving artists belongs to the nineteenth century. Bohemia, of course, was originally the name of a kingdom of Central Europe from whence the Gypsies supposedly came, but by mid-century it had acquired its wider meaning with the popular success of Henri Murger's play La Vie de Bohème in Paris in 1849 and the publication of an edition of Murger's sketches in 1851. The term must have reached London in the next few years, for in 1858 a New York Times writer mused that "bohemia" had traveled to New York via London rather than Paris. ${ }^{6}$

The notion of the bohemian resonated with an urban habit of mind already attuned, through journalists' sketches of the city and guidebooks to city life, to catalogues of "types" discovered and observed in their particular metropolitan niches. The "type" was a generic social 
specimen whom writers observed and recorded in voyeuristic gentlemen's rambles around the city. London, New York and Paris all had their "types": New York by Gas-light, for instance, written by Whitman's contemporary George C. Foster, described, among others, "the courtesan," "the newsboy," and "the seamstress" as the writer encountered them in "the fashionable assignation house," "the midnight eating-house," and "the tenement-lodging." This genre of urban writing highlighted particular city spaces as spectacles which compressed and condensed discrete images of metropolitan life. Thus in a culture already attuned to the exploration of far-away "exotic" lands and to the artifacts of such explorations - which ended up in exhibitions like those of New York's enormously popular Barnum's Museum - the metropolis itself became a cabinet-of-curiosities for its readers and strollers, the "bohemian" another sociological delectation. ${ }^{7}$

For nineteenth-century audiences, then, bohemia was a corner of the moral topography of the metropolis, an ecological niche peopled by identifiable types: a "Gipsy tribe" with a "loose and desultory nature," as the Times put it. Murger described the place as "bordered on the North by hope, work and gaiety, on the South by necessity and courage, on the West and East by slander and the hospital." Hostile critics characterized the terrain more dismissively, mostly as "a sad country." All could agree on the signs of membership: art, youth, libertinism and sexual adventure, rootlessness and, above all, opposition to bourgeois respectability. ${ }^{8}$

Yet as Jerrold Siegel has demonstrated in his work on Paris bohemians, on closer examination, the type begins to dissolve. Self-styled bohemians were not necessarily young, libertine, or rootless; they often existed in a symbiotic, rather than an oppositional, relationship to bourgeois convention. If bohemias were enclaves of dissent, they also provided some of their affiliates-beginning with Murger-an entrée to successful careers. Bohemian life was a wellspring of material for paintings, novels, plays and sketches pitched to middle-class audiences. Bohemia, Siegel argues, was not the thing apart its contemporaries believed it to be, but rather an imaginative enactment-in the popular press, on the city streets and within the sensibilities of its participantsof inchoate tensions between bourgeois life and artistic aspiration.

Certainly imagination was at work in the designation of Pfaff's beer cellar as a bohemia. Far from a pack of free-and-easy artistic vagabonds, the Pfaff's crowd consisted primarily of hard-working writers who made penurious livings from the penny press and magazines. Henry Clapp himself thought bohemia to be an entirely French phenomenon, impossible to transplant to America. ${ }^{9}$ At Pfaff's, libertinism and sexual adventurism were muted, with the one exception of Ada Clare, one of the few women regulars, who bore a child out of wedlock in a widely publicized 
scandal. It is possible that the overwhelmingly male bonhomie provided a congenial setting for men's attractions to each other: Whitman apparently met his working-class lover Fred Vaughan there, and consorted regularly with the young men of the "Fred Gray Association." 10 But in general, sexual bravado of any kind seems to have been absent, and neither homosexual nor heterosexual eroticism tinge any subsequent writing about Pfaff's. William Dean Howells, who as a tourist from Boston visited in 1860, remembered being disappointed at how lackluster were the libertines. The "orgy . . . went but slowly for an orgy" and mostly the New Yorkers pulled the earnest young writer's leg: "we were joined by some belated Bohemians whom the others made a great clamor over; I was given to understand they were just recovered from a fearful debauch; their locks were still damp from the wet towels used to restore them and their eyes were very frenzied. I was presented to these types who neither said nor did anything worthy of their awful appearance, but dropped into seats at the table, and ate of the supper with an appetite that seemed poor. I staid hoping vainly for worse things till eleven o'clock." 11

What underlay the typology of the bohemian, then, if not vagabondage and libertinism? The presence of women at Pfaff's suggests one possible answer. A handful of women artists figure in the accounts of New York bohemia: the writer Ada Clare, the actress Adah Issacs Menken, one Ada Clifton with a journalist beau, an unidentified Jenny Danforth, the actress Anne Deland, who came with her male companion/manager. Scattered references to these five raise the possibility that there might have been a few more unmarried women; respectable "wives" were absent. Whitman, reminiscing about Ada Clare, placed her in a context of other "girls," women of borderline respectability: "It is very curious that the girls have been my sturdiest defenders, upholders. Some would say they were girls little to my credit, but I disagree with them there." Perhaps he met some of these "girls" at Pfaff's along with Ada Clare. Clare, a George Sand-like confessional essayist and a militantly unrepentant unmarried mother, was enough of an urban curiosity in her own right to prompt Whitman to include her as a "sight" in his own urban guidebook, New York Dissected. ${ }^{12}$

Certainly, the presence of unmarried women, unchaperoned, in itself would have conjured up Parisian ateliers amd bistros. In nineteenth-century transatlantic urban culture, there were places where respectable women could go and places where they could not. Bohemian assumptions controverted this geography. Although there were differences in this respect among Paris, London and New York, in all three cities social conventions relegated respectable women to the private sphere of the home and legitimated their appearance in public only when men accompanied them. To frequent the streets, as working-class 
women did in the course of their daily routines, was to endure the taint of sexual availability. The only women who freely advertised their presence in public were prostitutes-literally, in New York parlance, "public women" or women "on the town."

A place like Pfaff's thus constituted quite a new kind of public space where, for all the sexual ambiguities, unaccompanied women were not automatically subject to sexual insult. The few women mentioned in connection with Pfaff's were not prostitutes - certainly in their own eyes and seemingly in the opinion of the men-although their unconventionality put them well outside the pale of bourgeois female respectability. Ada Clare was a well-known confessional essayist and novelist, defiant veteran of a notorious love affair with the pianist Louis Gottschalk; Adah Isaacs Menken was a successful actress (in 1860 she would achieve international notoriety as the star of a melodrama in which in the last scene, clad in flesh-colored tights and a G-string, she rode into the horizon lashed to the back of a "fiery steed"). ${ }^{14}$ On balance, however, the number of women was too tiny to account for Pfaff's reputation. At least at this moment, bohemian identity seems mostly detached from emerging questions about women's independence-although in the late nineteenth century bohemianism would become entirely bound up with the "woman question."

Rather, Siegel's analysis suggests that the more salient factor in the appearance of this new urban locale was a changed relationship between artists and cultural commerce. While Paris bohemia centered on painters, the New York bohemian was known as a writer. The Pfaff's conclave both announced and encouraged a refiguring of artistic ambition within an expanding literary market. In a culture in which pretensions to serious creativity had spread outside the cultural elite which once monopolized them, "bohemian" came to designate a new kind of writer.

It is in this context we can appreciate some reflections on bohemianism in the New York Times in January 1858. The Times took care to delineate the type, the "bohemian," as a bourgeois manqué: an aspiring artist "whose special aversion is work," "whose ambition is to excel in some particular walk for which Nature never designed him . . . perfectly reckless as to money, and decidedly given to debt; and with talent enough to gain wealth and reputation, he must always be next door to beggary." In the wake of the Panic of 1857 and mass demonstrations of the unemployed the previous fall, the editorialist was particularly troubled by what seemed to be the bohemians' willful disregard for honest work and middle-class status. "Unemployed doctors and blighted lawyers" with a taste for the arts were taking refuge in bohemia, and while this might be just a passing phase in the young men's development, those who remained were "lost irretrievably." Moreover, this corner of 
the metropolis seemed to encourage a confusion of class references. "Bohemian," a term which a short time before had been unknown in the New York lexicon, was now "heard as much as the once unknown term of the loafer." And while the bohemian was not quite a loafer, he was "not far removed from one."15

The "loafer," a coinage of the streets, was a beloved personage of Whitman's. While the term did not exclusively connote a working-class man, it was strongly tinged with a plebeian cast. So it is interesting that in the web of associations the Times sketched out, the bohemian seemed not at all a libertine, but rather now a middle-class slummer, now a working-class layabout. Indeed, what seems to have been disturbing about bohemia was its readiness to draw lowlife figures into the vicinity of respectable young men and, even more to the point, into the onceexclusive province of art.

\section{Literary Commerce and Bohemian Commerce}

What were the changes which encouraged bohemian loafers to indulge in Byronic ambitions? William Charvat some time ago sketched out the impact of commercialization and the opening of the Western market in the 1850s on Northeastern literary production. Recently, Ezra Greenspan has made a case for the ways in which in the 1850 s an economic and technological revolution in "all the factors involved in the creation, manufacture, marketing, and consumption of printed works" reshaped literary culture and in particular, "its most vociferous champion, Walt Whitman." David Reynolds has drawn attention to the proliferation of popular literature in that decade and to how the dialectical relationship between popular and serious writing reshaped genre and thematics in the literature of the American Renaissance. Reynolds cogently characterizes the 1850 s as "the arrival of literariness after its immersion in the popular."16

The touting of Pfaff's as a place of literary significance was an aspect of this more general "arrival of literariness." Most of bohemia's adherents were professional writers, part of a male milieu analogous to the networks of scribblers who had existed in Paris and London since the eighteenth century. These men lacked the private incomes that supported or cushioned lingering conceptions of the writer as gentleman of leisure, nor did they possess the government sinecures that, at midcentury, were becoming the substitute for well-connected men like Hawthorne and the unhappy Melville. They were socially and culturally remote from the avowedly literary centers of the city-the Century Club, the New York Historical Society, the American Copyright Club. ${ }^{17}$ Rather, these men were the journeymen of American writing, scrambling, like journeymen in other crafts, to make a living in a 
debased craft where new, proto-industrial relations rendered employment insecure and the pace of production ferocious. "Most of them were poor, and they were poorly paid," remembered the editor William Winter. "They were writers of remarkable ability, and they were under the stringent necessity of working continually and very hard." They depended mainly upon the penny press and, to a lesser extent, the magazines and literary weeklies - both innovations of mid-century. The newspapers created a constant and voracious demand for local interest stories, urban sketches and literary ephemera. Penny newspapers opened and folded all the time and with them editorial positions: by 1845, when he was 26 , Whitman had worked for ten different papers. Greenspan stresses how fluid the boundaries were for Whitman and his peers between literary professional roles-printer, reporter, editor, freelancer, periodical poet, story writer, bookseller, publisher. ${ }^{18}$ Writers also turned their hands to churning out crime pamphlets, temperance tracts, sentimental novels, political polemics, pornography, travel books and so forth. At one end, then, urban writing shaded into manual labor: printing was one path to editing and journalism (Whitman, Howells, and Mark Twain all started out as printers). At the other, it shaded into a profession for the broken and disappointed of the gentlemanly classes, as in the case of Poe a decade earlier or of the dashing Fitz-James O'Brien, a once wealthy Irishman and a Pfaffian in the late '50s who had arrived in New York with impressive letters of introduction to New York's most powerful editors, "a large and valuable library," "dressing cases; pictures; a ward-robe of much splendor; and all sorts of knick knackery, such as young bachelors love to collect."19

In terms of our own critical understanding, it is easy to associate this range of class positions with a spectrum of literary values, from "low" to "high," "popular" to "literary." But in fact the bohemians subverted easy equivalences between social class and literary ambitionif not always literary achievement. All the Pfaffian regulars were engaged in serious writing along with journalism: poetry (George Arnold, Whitman, N. G. Shepherd); short stories (O'Brien, Charles Gardette); and criticism (Clare, Clapp, Edward G. P. Wilkins). The proximity which Reynolds notes of the 'popular' to the 'literary' and the growing market for writing of all kinds-especially in the newspapers and magazines, which mixed poetry, short stories and essays with sketches and news-allowed hack writers, unconnected to the powerful institutions of literary taste and approbation, to begin to conceive of themselves as artists.

The gatherings at Pfaff's thus coalesced a sense of literariness among men who, from most other perspectives, were simply working stiffs. As a cultural space, its allure to Whitman-as to these other promising but as yet undistinguished writers-must have lain partly in 
its power to confer distinction on its habitués simply by virtue of their being there. By the twentieth century, the New York writers' bar was a commonplace of literary life, and there was a long line of such commercial institutions-Polly's Restaurant, the Algonquin, the White Horse Tavern, the Lion's Head-which cast over their patrons an aura of literary significance. But in the mid-nineteenth century, self-conscious literary life was confined to the gentlemen's clubs or to genteel mixed gatherings in private homes. The commercial democratic cultural space which gave an entrée to anyone with the price of a drink was quite new in America, an innovation of bohemia.

But Pfaff's charm as an insiders' hideaway stood in interesting tension to the fact that anyone could locate it: also in this as in other respects, bohemia was inextricable from the cultural marketplace. You might expect a bohemian retreat to have been located in some obscure neighborhood where artists of modest means resided; indeed, this would be the case later with the artists' bars tucked away in the involutions of Greenwich Village. Yet at this point in its history, New York was still delivering up its urban curiosities on the standardized plan of the grid. Pfaff's location on Broadway was at the hub of New York's "most intense cultural commerce," as William R. Taylor has described it, extending north along the avenue from City Hall Park. In his poem about Pfaff's Whitman evoked this placement within consumer spectacle and crowd:

The lamps are lit-the shops blaze in - the fabrics and jewelry are seen through the plate glass windows

The strong lights from above pour down upon them and are shed outside

The thick crowds, well-dressed-the continual crowds as if they would never end. . . .

The neighborhood was a premier shopping district and the center of Manhattan's nightlife, "offering a gaslit galaxy of theaters, hotels, restaurants, and saloons," in Martin Hyman's description. Within such a mixture of entertainment and shopping, Taylor argues in his essays on commercial culture, "the city's streets functioned as both showcase and show" for consumers of urban life. ${ }^{20}$

Pfaff's was, then, a kind of showcase for bohemians-perhaps in actuality, as urban tourists like Howells peered into its gloomy interior to take in the "sight," or perhaps only in the minds of its habitués. As strollers and urban tourists came to expect the streets themselves to provide a visual spectacle of urban diversities, so the bohemians provided for each other a theater of democratic, esthetic camaraderie. Pfaff's made this self-conscious spectacle available to a respectable audience these writers both courted and spurned. It offered a condensation of the bohemian life, providing a setting for elaborating an identity 
which went beyond the threadbare and seedy persona which was the mundane lot of the working writer.

\section{A Brooklyn Poet Becomes Manhattan Bohemian}

In the 1850 s, although he had published some fiction in the prestigious Democratic Review, Whitman was a minor feuilletoniste, a virtual outsider to the profession of "literariness." A modestly educated workingman, a printer and housebuilder, he was connected to other printers, journalists and editors in the city, but he lacked any association with New York's elite writers. In 1850, Paul Zweig points out, Whitman was indistinguishable from his "swarm of colleagues" as he dashed off one ill-paid sketch after another, "a floundering, almost middle-aged man, understandably possessed at times by feelings of 'torpor' and gloom." Five years later he published the first edition of Leaves of Grass, and received the critical acclaim of Emerson and others. Three years after that, however, in 1858 when he began to go to Pfaff's, he seemed to be headed right back to the "swarm." His great patron, Emerson, was far away in Boston and in any case far removed socially from the humbly born Whitman. His experience with publishers was still limited to the local phrenological firm Fowler \& Wells. Emerson had in any case cooled towards him after the publication of the racy second edition of Leaves of Grass, and so Whitman's weak ties to "literature" were further attenuated. To advance the work of revising Leaves of Grass, he pretty much had foregone other employment and was living at home. He had little experience with an active audience, since he had no poet friends in New York and his family was utterly uninterested in his work (his mother and brother George found Leaves to be "pretty much the same muddle" as Longfellow's Hiawatha). ${ }^{21}$

Biographers differ in interpreting the psychological cast of this period, with some supposing a heavy emotional cost from Whitman's continuing experiences of hostility and indifference, and others stressing the energy with which he seems to have bounded from one disappointment to another. But Whitman himself, at least in retrospect, described the aftermath of the second edition as a time of desolation. To Horace Traubel: "I don't know if you have ever realized it-ever realized what it means to be a horror in the sight of the people about you: but there was a time when I felt it to the full-when the enemy-and nearly all were the enemy then-wanted for nothing better or more than simply, without remorse, to crush me, to brush me, without compunction or mercy, out of sight, out of hearing: to do anything, everything, to rid themselves of me."22

It was at this juncture that bohemia played a crucial role in reanimating a faltering creative venture. In gravitating to Pfaff's, Whitman 
put himself for the first time in a daily relationship with writers who aspired to a kind of work beyond Grub Street. He participatedprobably for the first time-in self-consciously literary conversation. "We talked, discussed: all sorts of questions were up," Whitman told Traubel. There was gossip about other writers: Whitman scribbled down in his notebook the gist of a story he had heard from Charles Gardette about the rise and fall of the popular feuilletoniste, George Lippard; "was handsome Byronic,-commenced at 18-wrote sensation novels-drank-drank-drank-died mysteriously either of suicide or mania a potu at 25-or 6-a perfect wreck-was ragged, drunk, beggarly - ." There was verbal play with literary material: O'Brien took the idea for a sensationalist Poe-esque story about a glass eye from a story Clapp told one night. There were political fights: Whitman and the poet George Arnold fell out one evening over Arnold's pro-Southern remarks and Whitman also once got into a row for defending, in his determinedly world-encompassing fashion, Queen Victoria ("But in my philosophy ... there is plenty of room for all ... not only anarchists, socialists, whatnot, but Queens, aristocrats"). ${ }^{23}$

And there were rhetorical jousts of insult and badinage. The bohemians prided themselves on a sharp-edged repartee altogether opposed to the polite puffery of genteel literary circles. Henry Clapp, who set the tone, was known for his slashing wit and withering bon-mots: a disdain for puffery was a point of principle for his Saturday Press. Winter described a caustic collective style articulated through verbal facility, mockery and male bravado:

Candor of judgment, indeed, relative to literary product was the inveterate custom of that Bohemian group. Unmerciful chaff pursued the perpetrator of any piece of writing that impressed those persons as trite, conventional, artificial, laboriously solemn, or insincere; and they never spared each other from the barb of ridicule. It was a salutary experience for young writers, because it habituated them to the custom not only of speaking the truth, as they understood it, about the writings of their associates, but of hearing the truth, as others understood it, about their own productions. ${ }^{24}$

Memories like this convey an excitable, feverish atmosphere, emanating, I think, from the charged political climate of the 1850 s but, perhaps more importantly, from the superheated conditions of literary work. Clapp's correspondence with Whitman, for example, communicates the frantic anxieties of a literary sweatshop operating on a tiny margin of capital: "I am so busy that I hardly have time to breathe ... I am in the greatest possible difficulties on account of one or two past inabilities still ... I must have one hundred dollars before Saturday night or be in a scrape the horror of which keeps me awake 'o nights."25 Pfaff's was not a place where one went to wind down after a hard day's work; it was different from a workingman's saloon. Rather, it was an 
anteroom to the workshop, psychologically enmeshed with the affairs of writers, their bosses, their critics, friends and enemies. O'Brien, for example, would dash into Pfaff's to sponge off friends when he was dead broke, then dash out again with an idea for a story to knock off. ${ }^{26}$ And Whitman's strongest memory of Pfaff's was of "hearing the truth" about Leaves of Grass as it came straight from Printing House Square one night. While the printers and writers had waited around one Saturday evening for their pay, one of them, to pass the time, had pulled out a copy of Leaves of Grass and had given a mocking reading to the assemblage: "read it, made light of it: the others, too; the strokes bright, witty, unsparing." Someone then took the joke over to Pfaff's to regale the crowd there. By the time Whitman recounted the story to Traubel he was the Good Gray Poet, above vanity and resentment; he took care to assure his disciple there was no harm done. "You stood it easily," the latter inquired admiringly, "It did not disturb you, even at the time?" "Not at all: they did it for their amusement: I was inclined to let them be amused." "Good fellows, probably?" Traubel ventured, and Whitman answered heartily, "Yes, none better."27 Recast, the incident became a tribute to Whitman as "camerado." At the time, it must have hurt. Did the others at Pfaff's laugh with him or at him? Did mockery rankle less in a crowd where everyone came in for his share, where hostility and ridicule were assumed to be a writer's lot, and where, above all, one's identity as an artist was secured, not threatened, by being there to take it?

Whitman apparently took little part in what he called "rubbings and drubbings." He insisted that he had simply enjoyed sitting quietly at Pfaff's and watching: "I never was a great discusser, anyway."28 Whitman, of course, was always revising his past, and with this recollection - as with the anecdote of the "good fellows" who ridiculed Leaves of Grass - we sense the lineaments of the "ample, serene and masterful identity" Whitman favored in his later years. ${ }^{29}$ In contrast, Whitman's rendering of his evenings at Pfaff's with "the Fred Gray Association" conjures up animation, hilarity and "sparkle." But the question of Whitman's own participation is really irrelevant; what's more important is what he gained in professional certainty from his new literary friendships. By 1860, Kaplan notes, Whitman's "dealings with editors reflected a new self-regard and assertiveness." "The price is $\$ 40$. Cash down on acceptance," he flatly instructed Harper's when he submitted a poem, following this demand with detailed conditions for how high up his name should appear in the list of contributors and for rights to future reprints. ${ }^{30}$ Whitman's sense of his poetic vocation had never needed shoring up. But in the early stages of his career as a poet, he had had to depend on the patronage of the Boston critical establishment to achieve public notice. For a writer who was fundamentally an outsider, 
that older mode of patronage proved unreliable. Pfaff's taught him new ways to insert himself into the stream of national literary commerce, methods and strategies that did not depend on the moral approbation of the Boston literati and that accorded better with the sensibilities of the New York pressrooms and streets.

Whitman's gifts need to be understood, above all, as the generative powers of an artist. But it is also useful, I think, to explore those historical channels which allowed his powers to expand so astonishingly in such a short time. Bohemia was one space which encouraged the Brooklyn "loafer" and "rough" to reanimate his sense of his profession and his audience.

\section{Henry Clapp and New York Publishing}

"You will have to know something about Henry Clapp if you want to know all about me," Whitman mused to Traubel on turning up an old letter from Clapp in his rummages through his trunk. "I will tell you, sometime or other. We were very intimate at one time." This was the sort of evasion and half-glimpse which Whitman often used as a sexual code: perhaps the two had been lovers. He was "always loyalalways very close to me-in that particular period-there in New York." But whether or not Clapp was a lover, he certainly was a champion and a friend, "a much needed ally at that time . . . when almost the whole press of America when it mentioned me at all treated me with derision or worse." More simply: "Henry was my friend." And elsewhere, with one of his wonderful colloquialisms: "Henry Clapp stepped out of the crowd of hooters." 31

Clapp and Whitman were close in age (Clapp was 44 in 1858, Whitman 39) and shared a generational affiliation to radical reform. Born in Nantucket, Clapp had entered public life as an abolitionist lecturer in the 1830 s and had gone on to edit a temperance newspaper and then to work as secretary to the American Fourierist Albert Brisbane. It is more difficult to discern his political commitments in New York in the 1850s. His abolitionism, if it persisted, seems to have been separate from his literary work, since there is no discussion of slavery in his Saturday Press, and an editorial in 1858 calls for a literature freed from the concerns of party politics, "a vast brotherhood of thieves." But contempt for the parties in the late 1850s was widespread among antislavery radicals, and Clapp did appear that year at a star-studded convention of radicals in Rutland, Vermont - a gathering of spiritualists, free-thinkers, advocates of women's rights and free love, and abolitionists. $^{32}$

More salient, perhaps, to Clapp's friendship with Whitman was his involvement in free love circles. In 1855 he was arrested in a police raid 
on a meeting of the New York Free Love League, a discussion group of men and women presided over by the anarchist and sex radical Stephen Pearl Andrews. Clapp evidently played a leading role in "The Club": he was a speaker the night of the raid and presented the members' defense at the subsequent trial. ${ }^{33}$ Whitman was already acquainted with-and sympathetic to-several strains of reform thought: temperance, abolitionism and health reform. But the new friendship may have been his first encounter with free love ideas. As Zweig notes, by the 1850 s most forms of reform were too narrow for the self-styled representative man; his politics were closer to the body, the democracy of embrace. ${ }^{34}$ The highmindedness of free love ideology, its impiety towards conjugal sex, its insistence that erotic love, free of legalities and based on voluntary affection, could be spiritually transcendent: all this would have suited Whitman as he prepared the "Calamus" poems for publication.

By the time Whitman met him, however, Clapp sought a more protean oppositional identity than radical reform offered. He impressed others as a bohemian genius who set his entire existence against the forces of convention. W. L. Alden recalled him as "the wittiest man of his day, but his wit was always cynical and malign." (His bestremembered quip was about Horace Greeley - "a self-made man, who worshipped his creator": not bad, even 130 years later!) William Winter recalled a man

brilliant and buoyant in mind; impatient of the commonplace; intolerant of smug, ponderous, empty, obstructive respectability; prone to sarcasm; . . . he had for so long a time lived a continuous, bitter conflict with conventionality that he had become reckless of public opinion. His delight was to shock the commonplace mind and to sting the hide of the Pharisee with the barb of satire.

Howells, a far more astute observer, sensed the theatrical element in this self-presentation, perhaps because Clapp, in their one meeting in 1860, cast him so quickly as a "Pharisee" himself. Howells had eagerly sought Clapp out because he so admired the Saturday Press. "The young writers throughout the country were ambitious to be seen in it. . . . It is not too much to say that it was very nearly as well for one to be accepted by the Press as to be accepted by the Atlantic, and for the time there was no other literary comparison." But although Howells came to pay his respects, Clapp was intent on anything but a gracious response. Rather, he displayed a manner "of such a sort 'that if he was half as bad, he would have been too bad to be." " Howells figured as the bourgeois to be épaté. "He walked up and down his room saying what lurid things he would do directly if any one accused him of respectability. There were four or five of his assistants and contributors listening to the dreadful threats, which did not deceive even so great innocence as mine. They probably felt the fascination for him which I could not disown, in spite 
of my inner disgust; and were watchful at the same time for the effect of his words with one who was confessedly fresh from Boston." 35

Howells' mistake was to be from Boston. We can view the entire account of his meeting with Clapp as materializing from his decadeslong battle against the ascendancy of New York over his beloved Boston as literary capital of the country. Howells was both drawn to the literary dynamism of New York and repelled by it, and he preserved until the end of his life a nostalgia for the well-bred Boston literary elite which had enfolded him in their circle when he first migrated to the city from the Midwest in 1861. For Howells, Clapp's "bad" qualities were inseparable from his New-York-ness: "he embodied the new literary life of the city." And at the heart of that life was a contempt for Boston, "a bitterness against Boston as great as the bitterness against respectability."36

Given the long dominance of New York in publishing and literary politics, it is difficult now to conceive of its writers as remote from literary connections and prestige, but this was indeed only beginning to change in the 1850s. The critic Edmund Clarence Stedman remembered the decade as bleak: "there was not much of a literary market at that time." Newspaper work was badly paid; only Harper's (New York) and The Atlantic (based in Boston) paid decently; "New York itself was not literary and looked with distrust, if not contempt, upon working writers." Winter asserted that "a harder time for writers has not been known in our country than the time that immediately preceded the outbreak of the Civil War" and amplified his claim by recounting the hard-luck stories and early deaths of many of the Pfaff's regulars. ${ }^{37}$

But as Charvat has shown, the material resources for a different configuration of literary power had begun to materialize. Within the expansion of literary commerce at mid-century, New York began to outstrip Boston and Philadelphia. The Erie Canal and the railroads opened the western market to New York rather than Boston: a constant stream of New York papers, magazines and novels made their way to Midwestern bookstores and general stores. The Saturday Press, for example, which appears to us now as an obscure journal of an obscure avant-garde, had reached Howells in Columbus, and loyal readers in Cincinnati clubbed together to receive their parcels. ${ }^{38}$ The city's publishers and writers were just beginning to take advantage of the possibilities the new markets offered for a publishing business free of the dominance of the Boston critics and publishers. Clapp was a leader in this process, and Whitman would in some ways be its first great success.

Clapp's prescience lay in his comprehension of how publicity and celebrity could, within a changing literary market, obviate the need for critical and moral approval. Whitman seemed to have something of this in mind when he noted that Clapp was the writers' avant-garde, "our 
pioneer, breaking ground before the public was ready to settle." At a moment when some gentleman writers still shied away from advertising their books, Clapp fully grasped the democratizing features of the market. "It is a fundamental principle in political economy," he instructed Whitman in 1860, "that everything succeeds if money enough is spent on it." From this perspective, Whitman's scandalous erotic poetry was an asset not a liability. Clapp took the hostility of the critics and turned it on its head, cheerfully publishing, for example, Juliette Beach's revolted review of the third edition. As Whitman remembered, "Henry was right: better to have people stirred against you if they can't be stirred for you-better that than not to stir them at all."39

Clapp put this precept into practice for Whitman by "stirring up" continually in the pages of the Saturday Press the matters of Leaves of Grass, and, moreover, that of the poet himself. The Press took as its subject not only the work but the writer. Eugene Lalor found twenty items on Whitman appearing over a period of eleven months. There were contributions by Whitman ("Out of the Cradle Endlessly Rocking" first appeared in the Press as "A Child's Reminiscence"), reviews and notes pertaining to Leaves, advertisements and parodies of the poet's style. ${ }^{40}$ Clapp reprinted negative as well as positive reviews from other journals. Scarcely a week went by, observed Albert Parry, without some reference to Whitman. The normally boastful Whitman even seems to have sought to restrain Clapp's enthusiasm on one occasion: "I meant to have done more last week," Clapp wrote him in March 1860, "but followed your advice and made a modest and copyable announcement." Newspapers all over America had noticed Whitman's poem in The Atlantic and had mounted an attack, Clapp went on to report with martial zest, "which I take to be good for you and your new publishers, who if they moved rapidly and concentrate their forces will make a Napoleonic thing of it."

Clapp's new set of rules of writerly entrepreneurship found a willing and seasoned follower in Whitman, who had already pioneered the art of self-promotion with his anonymous reviews of the first edition of Leaves and his brash inclusion of Emerson's blurb on the spine of his 1856 edition. These were New York's rules, not Boston's, predicated on manipulating money and publicity rather than social connections and patronage. This ethic of advertising and self-promotion would be associated with New York's rise to literary eminence in the next three decades and with the growing prominence given to New York authors in the national cultural arena. This shift was predicated, I've noted, on economic changes in transportation and marketing. But it also involved successful efforts by certain New York writers to seize upon an urban sensibility fascinated by spectacle and 'type' and to create a different sort of image of the artist in the metropolis. 
What we would call the "celebrity" lay close at hand, the unique personage whose special attributes materialized in a setting of companions/compatriots. Urban tourists on the prowl might come upon a celebrity - a notorious criminal, a famous actress - in their travels around town.

When the young Howells set out "to explore the literary situation of the metropolis," his first trip to New York, he made bohemia his focus, with a first stop at the offices of Henry Clapp's Saturday Press and a second at Pfaff's. The highlight of the pilgrimage-at least as Howells viewed it much later through the prism of Whitman's fame-was encountering the poet whom he already admired. "The night of my visit he was the chief fact of my experience," perhaps having heard of him from some of the Boston luminaries who patronized Whitman-or from reading the Saturday Press:

I did not know he was there till I was on my way out, for he did not sit at the table under the pavement, but at the head of one further into the room. There, as I passed, some friendly fellow stopped me and named me to him, and I remember how he leaned back in his chair, and reached out his great hand to me, as if he were going to give it me for good and all. He had a fine head, with a cloud of Jovian hair upon it, and a branching beard and mustache, and gentle eyes that looked most kindly into mine . . . and . . . though we hardly passed a word . . . our acquaintance was summed up in that glance and the grasp of his mighty fist upon my hand. ${ }^{42}$

Pfaff's hand supported the loafer, by then quite a few months unemployed, in biding his time as a bohemian. Pfaff's also brought him into the vicinity of the interested urban tourist, and in so doing the particularities of his identity and gifts began to emerge from an urban type. The lineaments of a celebrity, the Good Gray Poet, soon available to a much broader audience, were beginning to appear. Whitman had found a place where he could be sought after, viewed from afar, long remembered.

Princeton University

\section{NOTES}

1 A standard account of Whitman at Pfaff's is in Albert Parry, Garrets and Pretenders (New York: Covici, Friede, 1933), Chapter 4; see also his "Life in Old Bohemia," The American Mercury 21 (November 1930), 364-371. The quote comes from Horace Traubel, Walt Whitman in Camden (New York, 1908; New York: Roman and Littlefield, 1961), 1:417. The best scholarly source on the Pfaffians is Eugene Lalor, "The Literary Bohemians of New York City in the Mid-Nineteenth Century," Ph.D. diss., St. Johns University, 1977.

2 Whitman, Notebooks and Unpublished Prose Manuscripts, ed. Edward F. Grier (New York: New York University Press, 1984), 1:454-455. Hereafter NUPM. 
3 Frederick Schyberg, Walt Whitman (Copenhagen, 1933; New York: Columbia University Press, 1951), 143. Schyberg was trying to make his way around the evidence of Whitman's homosexuality. The Binns quote is from Henry Binns, A Life of Walt Whitman (London: Methuen, 1905), 141.

4 Paul Zweig, Walt Whitman: The Making of a Poet (New York: Basic Books, 1984), 263-265.

5 Justin Kaplan, Walt Whitman: A Life (New York: Simon and Schuster, 1980), 246; Zweig, 295-296.

6 Jerrold Siegel, Bohemian Paris: Culture, Politics, and the Boundaries of Bourgeois Life, 1830-1930 (New York: Viking, 1986), Chapter 1; Joanna Richardson, The Bohemians: La Vie de Bohème in Paris 1830-1914 (South Brunswick, NJ: A. S. Barnes, 1971), 102-105; New York Times, January 6, 1858.

7 George G. Foster, New York by Gas-light, ed. Stuart M. Blumin (Berkeley: University of California Press, 1990). On urban exploration see Deborah Epstein Nord, "The Social Explorer as Anthropologist: Victorian Travellers Among the Urban Poor," in Visions of the Modern City, ed. William Sharpe and Leonard Wallock, Proceedings of the Heyman Center, Columbia University, c. 1983. On urban spectacle, see William R. Taylor, In Pursuit of Gotham: Culture and Commerce in New York (New York: Oxford University Press, 1992), Chapter 3.

8 Siegel, 3.

9 "Bohemia," Saturday Press (New York), March 3, 1860.

10 On Ada Clare, see Parry, 14-37, and Charles Warren Stoddard, "Ada Clare: Queen of Bohemia," National Magazine (September 1905); on the Fred Gray Association, see Whitman, NUPM 2:487, 490, 492; and The Correspondence, ed. Edwin Haviland Miller (New York: New York University Press, 1961), letter 62 [before 8/7/1863], 1:123-124; and Miller's introduction, 10-11. Whitman also took young doctors to Pfaff's whom he had met while visiting the sick at the New York Hospital: the reminiscences of one doctor are reprinted in Richard Henry Stoddard, "The World of Letters," Mail and Express (New York, June 20, 1893), reprinted in Whitman, NUPM 2:528. There are numerous references to particular men Whitman encountered at Pfaff's throughout NUPM.

11 Howells, Literary Friends and Acquaintances (1900; Bloomington: Indiana University Press, 1968), 65.

12 Ada Clare is mentioned in virtually all memoirs of Pfaff's. Jenny Danforth is mentioned in Stedman, Life and Letters, 1:207; Ada Clifton in an article reprinted in William S. Walsh, Pen Pictures of Modern Authors (New York: G. P. Putnam's Sons, 1882), 164; Anne Deland in Parry, "Life in Old Bohemia," 366; Adah Menken in Gay Wilson Allen, The Solitary Singer (New York: Macmillan, 1955), 262. Dr. Roosa states firmly that only men frequented places like Pfaff's-i.e., no respectable woman would enter-in Stoddard, "The World of Letters." W. L. Alden described the genteel literary parlor circles in which writers" "wives" did play an active role in "Some Phases of Literary New York in the Sixties," Putnam's Monthly 3 (October 1907-March 1908): 554-557. Whitman's quote is in Traubel, Walt Whitman in Camden, 3:117; Ada Clare appears in New York Dissected (New York: Rufus Rockwell Wilson, 1936), 131, 232 233n, and also as a "sight" in "Street Yarn" in Life Illustrated (New York), September $16,1856$. 
13 I've written about gender and urban public space extensively in City of Women: Sex and Class in New York, 1789-1860 (New York: Knopf, 1986); see especially chapters 3, 5,9 and 10 .

14 See Clare's autobiographical novel, Only a Woman's Heart (New York: M. Doolady, 1866); on Menken, see Allen, 262, and Bernard Falk, The Naked Lady: A Biography of Adah Isaacs Menken (London: Hutchison, 1934).

15 New York Times, January 6, 1858.

16 William Charvat, The Profession of Authorship in America, 1800-1870, ed. Matthew J. Bruccoli (Columbus: Ohio State University Press, 1968); Ezra Greenspan, Walt Whitman and the American Reader (Cambridge: Cambridge University Press, 1990), 12; David S. Reynolds, Beneath the American Renaissance (Cambridge: Harvard University Press, 1989), 9.

17 On New York clubs, see Perry Miller, The Raven and the Whale: The War of Words and Wits in the Era of Poe and Melville (New York: Harcourt, Brace, 1956), passim; Alden, "Some Phases of Literary New York," 558.

18 Winter, Old Friends, Being Literary Recollections of Other Days (New York: Moffat, Yard, 1909), 66-78, 95-106; Kaplan, Walt Whitman, 104; Greenspan, Walt Whitman, 25-26. See also the excellent article on New York journalism by Steven H. Jaffe, "The History of the Future' . . . Whitman and the New Journalism," Seaport 26 (Spring 1992), 26-31.

19 Winter, Old Friends, 66-78, 95-106. The recollection of O'Brien's material effects is on p. 99.

20 Martin Hyman, “' 'Where the Drinkers and Laughers Meet'; Pfaff's: Whitman's Literary Lair," Seaport 26 (Spring 1992): 57; Taylor, In Pursuit of Gotham, 70.

21 Zweig, 201; Horace L. Traubel, "Notes from Conversations with George W. Whitman," In Re Walt Whitman (Philadelphia: David McKay, 1893), 35.

22 Traubel, WWC 3:118.

23 WWC, 3:116; NUPM 1:434; Winter, Old Friends, 69; Walsh, Pen Pictures 166; Whitman, Daybooks and Notebooks, ed. William White (New York: New York University Press, 1978), 2:492n.

24 Winter, Old Friends, 96.

25 Letter reprinted in WWC 1:237-238.

26 Winter, Old Friends, 70-72.

27 WWC 3:116-117.

28 WWC 1:417.

29 The description is Kaplan's: Walt Whitman, 19.

30 Kaplan, 246.

31 Traubel, WWC 1:214, 236; 2:375; 1:236. Much has been written on Walt Whitman's codes for his love of men: I found especially helpful Alan Helms, " "Hints . . . Faint Clews and Indirections': Whitman's Homosexual Disguises," in Walt Whitman Here and Now, ed. Joann P. Krieg (Westport, CT: Greenwood, 1985), 61-67. 
32 Information about Clapp's background comes from Winter, Old Friends, 59-61. The quote is from the Saturday Press, November 6, 1858. On the Free Convention see Proceedings of the Free Convention, held at Rutland, Vermont . . 1858 (Boston, 1858).

33 Taylor Stoehr, Free Love in America: A Documentary History (New York: AMS Press, 1979), 319-320.

34 Zweig, 227. Sherry Ceniza suggests that Whitman may have heard free love ideas from Abby Price, who had lived with the Fourierists; see "Walt Whitman and Abby Price," Walt Whitman Quarterly Review 7 (Fall 1989), 49-67.

35 Alden, "Some Phases of Literary Life," 557; Winter, Old Friends, 58; Howells, Literary Friends, 61-64.

36 Howells, pp. 63-64.

37 Edmund C. Stedman, Life and Letters of Edmund Clarence Stedman, ed. Laura Stedman and George M. Gould (New York: Moffat, Yard, 1910), 209; Winter, Old Friends, 82.

38 Saturday Press, November 6, 1858.

39 Whitman to Traubel in WWC 1:238; Traubel to Whitman in WWC 2:375; Whitman in $W W C$ 1:237. The Beach review appeared in the Saturday Press, June 2, 1860, blithely followed by a laudatory review of Leaves in the June 16 issue.

40 Lalor, “The Literary Bohemians," 51-54. Greenspan, 210-213, details Clapp's efforts.

41 Parry, Garrets and Pretenders, 40; Clapp to Whitman in Traubel, WWC 1:237.

42 Howells, 67. 